\title{
The Classification of Children Gadget Addiction: The Employment of Learning Vector Quantization 3
}

\author{
Okfalisa $^{1}$, Elvia Budianita ${ }^{2}$, Musa Irfan ${ }^{3}$, Hidayati Rusnedy ${ }^{4}$, Saktioto $^{5}$ \\ Department of Informatics, Universitas Islam Negeri Sultan Syarif Kasim Riau, Indonesia ${ }^{1,2,3,4}$ \\ Department of Physics, Universitas Riau, Indonesia ${ }^{5}$ \\ okfalisa@gmail.com¹, elvia.budianita@uin-suska.ac.id², musairfan1011@gmail.com³, \\ hidayatirusnedy87@gmail.com ${ }^{4}$, saktioto@yahoo.com ${ }^{5}$
}

\begin{tabular}{l}
\hline Article Info \\
\hline Article history: \\
Received Oct 10, 2020 \\
Revised Oct 14, 2020 \\
Accepted Nov 11, 2020 \\
\hline
\end{tabular}

\section{Keyword:}

Classification

Neural Networks

Gadget Addiction

Learning Vector Quantization 3

Machine Learning

\begin{abstract}
The addiction of children to gadgets has a massive influence on their social growth. Thus, it is essential to note earlier on the addiction of children to such technologies. This study employed the learning vector quantization series 3 to classify the severity of gadget addiction due to the nature of this algorithm as one of the supervised artificial neural network methods. By analyzing the literature and interviewing child psychologists, this study highlighted 34 signs of schizophrenia with 2 level classifications. In order to obtain a sample of training and test data, 135 questionnaires were administered to parents as the target respondents. The learning rate parameter $(\alpha)$ used for classification is $0.1,0.2,0.3$ with window $(\mathcal{E})$ is $0.2,0.3,0.4$, and the epsilon values (m) are $0.1,0.2,0.3$. The confusion matrix revealed that the highest performance of this classification was found in the value of 0.2 learning rate, 0.01 learning rate reduction, window 0.3 , and 80:20 of ratio data simulation. This outcome demonstrated the beneficial consequences of Learning Vector Quantization (LVQ) series 3 in the detection of children's gadget addiction.
\end{abstract}

(C) This work is licensed under a Creative Commons AttributionShareAlike 4.0 International License.

\section{Corresponding Author:}

Okfalisa

Department of Informatics

Universitas Islam Negeri Sultan Syarif Kasim Riau,

Jl. HR. Soebrantas Panam Km. 15 No. 155 Kec. Tampan, Kabupaten Kampar, Riau 28293, Indonesia

E-mail: okfalisa@gmail.com

\section{INTRODUCTION}

The digital era emphasizes the use of technology, which leads to a toolkit that is indispensable instead of essential. Common Sense Media in America has reported a five-fold rise in gadget ownership for families with children aged 8 years and below [1]. This is due to the inclusion of parents to their children of this emerging technology in accessing the learning medium, games, entertainment, and social media [2][3][4]. Unfortunately, the lack of parents' supervision creates the abuse of gadgets thus triggers the children to be a gadget addiction [5]. The children's gadget addiction is measured by the high duration of gadgets used, the gadget dependence, and the uncontrolled utilization of that technology [6] [7] [8]. Thus, Unfortunately, the lack of supervision by parents ended up causing gadget misuse, thus prompting children to become addicted to gadgets 
[5]. The addiction of children to gadgets is determined by the high duration of the gadget employed, the vulnerability of gadgets, and the poorly regulated use of that technology [6][7][8]. This, therefore, yields the embracing of mental disorders, such as issues of insomnia and social behavior [9-11]. Anxiety identification triggered by addiction must be recognized early on. Since the condition of their children is normally hard for parents to comprehend. This research attempts to determine the degree of children's addiction to gadgets.

Warren McCulloch and Walter Pitts (1943) [12] first introduced the Artificial Neural Network (ANN) and used it to simulate brain computation, thereby potentially replacing conventional modeling approaches such as the statistical model [13]. In response to errors between actual output values and target output values, the ANN will learn by attempting to change weights between neurons and mirroring a human's function [14]. LVQ is a category of nonlinear ANN models that environmental-resistant and supportive of training and extracting rich data [15] for classification problems [16]. For acquiring class-labeled classifiers, the original LVQ algorithms and most modern extensions use supervised learning. However, through unsupervised learning for clustering purposes, LVQ can also be trained without labels [17]. LVQ classifiers are especially intuitive and easy to understand since they are generally based in the input space on the notion of class members and class regions. The cost of constructing LVQ algorithms refers to the number of prototypes that are typically compared to multilayer perceptron or support vector machines (SVM) with a fixed number. Instead, SVMs take into account the number of training datasets and have minimum dataset margins.

In a nutshell, a valuable alternative to SVM has been shown by LVQ [18] [17]. Barbara et al (2020) reviewed that LVQ significantly improved with an accuracy of above $99 \%$ and with Kappa greater than 0.99 compare to three types of different classification models [19], including discriminant analysis and other linear classification models such as Linear Discriminant Analysis (LDA), Regularized Discriminant Analysis (RDA), Mixture Discriminant Analysis (MDA), and Partial Least Squares Discriminant Analysis (PLS-DA); nonlinear classification models such as Artificial Neural Networks (ANN), Support Vector Machine (SVM) with a radial kernel function, kNearest Neighbors (k-NN), Naive Bayes (NB), and Learning Vector Quantization (LVQ); and classification trees and rule-based models such as Classification and Regression Tree (CART), Bagging, Random Forest (RF), C5.0, and Generalized Boosted Machine (GBM).

LVQ classifiers aim to approximate the Bayesian theoretical boundary and provides deal with multi-class issues directly. The initial rules for LVQ learning were heuristic and showed the initialization sensitivity, slow convergence issues, and instability. In order to ensure the convergence, the initial LVQ algorithm lack to relate the cost function. Therefore, some enhancements such as LVQ2.1, LVQ3, work to create a higher speed of convergence or better Bayesian dividing line approximation. The original LVQ1 corrected only the prototype of the winner. The prototypes were pulled away from the class boundaries by this algorithm. LVQ1 assumes a good initial network state, which is why a method of preprocessing is required. Sensitivity to overlapping datasets is also recognized, but some neurons fail to learn the patterns of training. Throughout each step, the LVQ2 algorithm updates two vectors, the winner and the runner-up. The purpose is to determine the decision border differentially against the decision border of the theoretical Bayes. However, this function considers improvements that are only error-dependent and present those instabilities. By incorporating a stability factor [20][17], LVQ3 reverses the LVQ2 convergence problem consisting of the location of prototypes changing in continuous learning.

LVQ3 is versatile and easily adapted to boost the partitioning of data from different prototypes of the corresponding training sets, such as nearest neighbor (PNN), vector quantization (VQ), and support vector machines (SVM). LVQ3 has been successfully demonstrated by SangWoon and Oommen (2002) to increase the yields of the extensively studied prototype condensation scheme and to better represent the distribution of pattern examples [21]. Israel and Hugo (2015) have greatly enhanced the LVQ3 learning rule based on Granular Computing, thus attempting to make LVQ a simpler and low-cost clustering computing operation, properly covering class distribution, and upholding the desired reduction rate [22]. 
Indeed, this study threatened to take additional benefit of LVQ3 in resolving the classification of gadget dependency among children. Thus, it contributes a reasonable diagnosis in acknowledging the early state of child addiction.

\section{The Formulation of symptoms in Children Gadget Addiction}

Reviewing thorough literature and justified by a child psychologist from Psychologist Consulting Bureau of Psychodata in Riau province 34 symptoms of children gadget addiction was defined in Table 1.

Table 1. The formulation of symptoms for children gadget addiction

\begin{tabular}{|c|c|c|c|}
\hline No & Symptoms & Sub Symptoms & References \\
\hline 1 & $\begin{array}{l}\text { Children's school } \\
\text { achievements }\end{array}$ & $\begin{array}{l}\text { 1.1 Children perform excellently } \\
1.2 \text { Children performs underachievers }\end{array}$ & $\begin{array}{l}{[23] ; \quad[24] ; \quad[25] ;} \\
{[26]}\end{array}$ \\
\hline \multirow[t]{2}{*}{2} & $\begin{array}{l}\text { Eye problems due to } \\
\text { the gadget addiction }\end{array}$ & $\begin{array}{l}\text { 2.1 Children endures eye problems } \\
\text { 2.2 Children's eye keep healthy }\end{array}$ & {$[27] ;[25] ;[28]$} \\
\hline & & $\begin{array}{l}\text { 3.1 Children tend to get angry when } \\
\text { parents overtake gadgets } \\
\text { 3.2 Children immediately get angry } \\
\text { when the parent overtake the gadget } \\
\text { 3.3 Children show the grumble act } \\
\text { when their parents refuse to permit } \\
\text { the gadget }\end{array}$ & \\
\hline \multirow[t]{6}{*}{3} & Role of Parents & $\begin{array}{l}\text { 3.4 Children stay focus on their } \\
\text { activities and lets parents' takeover } \\
\text { the gadget }\end{array}$ & $\begin{array}{l}{[29] ;} \\
{[30] ; \quad[25] ; \quad[31] ;} \\
{[26]}\end{array}$ \\
\hline & & $\begin{array}{l}\text { 3.5 Children answers honestly about } \\
\text { their time consuming the gadget }\end{array}$ & \\
\hline & & 3.6 Children lies & \\
\hline & & $\begin{array}{l}\text { 3.7 Children greet parents during their } \\
\text { gadget time }\end{array}$ & \\
\hline & & $\begin{array}{l}\text { 3.8 Children ignores their parents } \\
\text { during gadget time }\end{array}$ & \\
\hline & & 4.1 Children play educational games & \\
\hline \multirow[t]{2}{*}{4} & Game on gadget & $\begin{array}{l}\text { 4.2 Children play in addition to } \\
\text { educational games }\end{array}$ & {$[32] ;[25]$} \\
\hline & & $\begin{array}{l}\text { 5.1 Children tell more about school } \\
\text { activities rather than gadgets } \\
\text { 5.2 Children tell more about games and } \\
\text { gadgets }\end{array}$ & \\
\hline \multirow[t]{5}{*}{5} & Children socialization & $\begin{array}{l}\text { 5.3 Children avoid friends who are } \\
\text { telling more about gadgets }\end{array}$ & {$[33] ;[25] ;[9] ;[26] ;$} \\
\hline & & $\begin{array}{l}\text { 5.4 Children are excited to tell about } \\
\text { games on the gadget }\end{array}$ & \\
\hline & & 5.5 Children are sociable & \\
\hline & & $\begin{array}{l}\text { 5.6 Children have difficulty in } \\
\text { socialization }\end{array}$ & \\
\hline & & $\begin{array}{l}\text { 6.1 Children control its gadget playing } \\
\text { time }\end{array}$ & \\
\hline \multirow[t]{2}{*}{6} & Children's playtime & $\begin{array}{l}\text { 6.2 Children uncontrollable its gadget } \\
\text { playing time }\end{array}$ & $\begin{array}{l}{[37] ;[25] ;[34] ;} \\
{[35]}\end{array}$ \\
\hline & & $\begin{array}{l}\text { 6.3 Children gadget play time less than } \\
6 \text { hours/day }\end{array}$ & \\
\hline
\end{tabular}




\begin{tabular}{l}
$6.4 \begin{array}{l}\text { Children gadget play time more } \\
\text { than } 6 \text { hours / day }\end{array}$ \\
$7.1 \begin{array}{l}\text { Children routine activities such as } \\
\text { bathing and eating are interfered } \\
\text { with by gadget, especially during a } \\
\text { vacation day }\end{array}$ \\
$7.2 \begin{array}{l}\text { Children routine activities such as } \\
\text { bathing and eating are not affected } \\
\text { by the gadget, especially during a }\end{array}$ \\
vacation day \\
7.3 Children sleep pattern is disturbed \\
$7.4 \begin{array}{l}\text { Children sleep pattern as routine } \\
7.5 \text { Children spend their spare time } \\
\text { reading }\end{array}$ \\
$7.6 \begin{array}{l}\text { Children spend their spare time on } \\
\text { the gadget }\end{array}$ \\
$7.7 \begin{array}{l}\text { Children eat normally without any } \\
\text { gadget }\end{array}$ \\
$7.8 \begin{array}{l}\text { Children use gadgets while eating } \\
7.9 \begin{array}{l}\text { Children more attract to play with } \\
\text { friends rather than playing with } \\
\text { gadgets }\end{array} \\
7.10 \text { Children play with gadgets together } \\
\text { with friends }\end{array}$ \\
\hline
\end{tabular}

\section{RESEARCH METHOD}

This research begins by identifying problems related to gadget addiction in children using the learning vector quantization (LVQ3) method. Data collection was conducted through the reviews of literature and interviews with a child psychologist. As a result, 34 symptoms of children's addiction were defined as described in Table 1. This turns into grounded instrument development as well as a questionnaire. Moreover, the interview was justified two levels of children's addiction performance, including the high and low level of addiction [25]. To date with sampling data, 135 questionnaires were distributed to parents using google form at 5-6 Public Elementary Schools with an age range from 11-12 years. The parents were asked the diagnosing of their children's symptoms using 5 Linkert scales as strongly agree up to strongly not agree. Preparing the input data, a child psychologist was asked her verification on the questionnaires in determining the children's level of gadget addiction whether in high or low performance. Subsequently, two kinds of sharing data as well as training and testing data were construed within 78 data for low children addiction and 57 data for high children addiction. The next stage is following by normalization thus it ensures the standardized data before LVQ3 is performed. Herein, the range values 0 and 1 were applied for normalization. The normalization formula is defined in Equation (1).

$$
X *=\frac{X-\min (X)}{\max (X)-\min (X)}
$$

LVQ 3 algorithm is executed by considering the parameters and step process as follows at Figure 1 [39].

1. $X$ are training vectors $(X 1 \ldots X i \ldots X n)$.

2. $\quad T$ is the target of the class for the training vectors.

3. $W j$ is the initial weight vector in the $j^{\text {th }}$ unit $(W 1 j \ldots W i j \ldots W n j)$.

4. $C j$ is a class that represents the $j^{\text {th }}$ unit of output. 
5. Learning $\operatorname{rate}(\alpha), \alpha$ is defined as the level of learning. If $\alpha$ is too big, the algorithm will be unstable, on the other hand, if $\alpha$ is too small, the process will take too long. The value of $\alpha$ is $0<\alpha<1$.

6. The value of the learning rate reduction, namely the decrease in the level of learning

7. Minimum learning rate (Min a), which is the minimum value of the level of learning that is still allowed. The reduction in $\alpha$ value used in this study was $0.01 * \alpha$.

8. The $m$ epsilon value is the second $\alpha$ level of learning.

9. Calculate the Euclidean distances for vector $W$ and vector $X$

$$
X: \sqrt{(X+W)^{2}}
$$

10. Correct $W j$ with the condition If $T=C j$ then

$$
W j(n e w)=W(\text { old })+\alpha(X i-W j)
$$

11. If $T \neq C j$, check the runner-up distance whether it is still under $T$

12. The window value $(\varepsilon)$, which is the value used as the area that must be met to update the winner reference vector $(Y c 1)$ and runner-up $(Y c 2)$ if they are in different classes. Parameters $d c 1, d c 2 \ldots . d c n$ were acknowledged as the nearest distance values.

$$
\text { Equation window }(\varepsilon) \text { : Min }(d c 1 / d c 2, d c 2 / d c 1)>(1-\varepsilon)(1+\varepsilon)
$$

13. If the window condition $(\varepsilon)$ is satisfied, then the reference vector which does not belong to the same class as the vector $x$ will be updated using the equation:

$$
\begin{aligned}
& Y c 1(t+1)=Y c 1(t)-\alpha(t)[x(t)-Y c 1(t)] \\
& Y c 2(t+1)=Y c 2(t)+\alpha(t)[x(t)-Y c 2(t)]
\end{aligned}
$$

15. But if the condition in the window is false and both belong to the same class, the weight is updated using the equation (Teuvo Kohonen, 1996):

$$
\begin{aligned}
& Y c 1(t+1)=Y c 1(t)+\beta(t)[x(t)-Y c 1(t)] \\
& Y c 2(t+1)=Y c 2(t)+\beta(t)[x(t)-Y c 2(t)] \\
& \text { Learning rate } \beta(t)=\text { epsilon } * \alpha
\end{aligned}
$$

To trace the operation of the LVQ3 algorithm, a prototype system was then developed using the structural system development with the Waterfall model. The analysis adopted the Data Flow Diagram (DFD) and Entity Relationship Diagram (ERD) in designing process activity and data requirement analysis. To evaluate the effectiveness of LVQ 3 algorithm, confusion matrix was calculated with variant values of learning rate at $0.1,0.2,0.3$, window values at $0.2,0.3,0.4$, and epsilon values at $0.1,0.2,0.3$. The confusion matrix is an established way of visualizing the class errors, and performance analysis systems [40]. The simulation was also traced with three types of the environment at 70:30,80:20, and 90:10. The confusion matrix formula is explained in Equation (10) and (11). Meanwhile, Blackbox testing and User Acceptance Test (UAT) was delivered in figuring out the prototype software development. 


$$
\begin{aligned}
& \text { Accuracy }=\frac{T P+T N}{P+N} \times 100 \% \\
& \text { Error }- \text { rate }=\frac{F P+F N}{P+N} \times 100 \%
\end{aligned}
$$

$\mathrm{TP}($ True Positive $)=$ The amount of correctly classified data (Actual class (yes), Predicted class (yes)).

TN $($ True Negative $)=$ The amount of correctly classified data (Actual class (no), Predicted class (no)).

FN (False Negatif) $=$ The amount of incorrectly classified data (Actual class (yes), Predicted class (no)).

FP (False Positif) $=$ The amount of incorrectly classified data (Actual class (no), Predicted class (yes)).

$P=$ Total of TP and FN

$N=$ Total of FP and TN

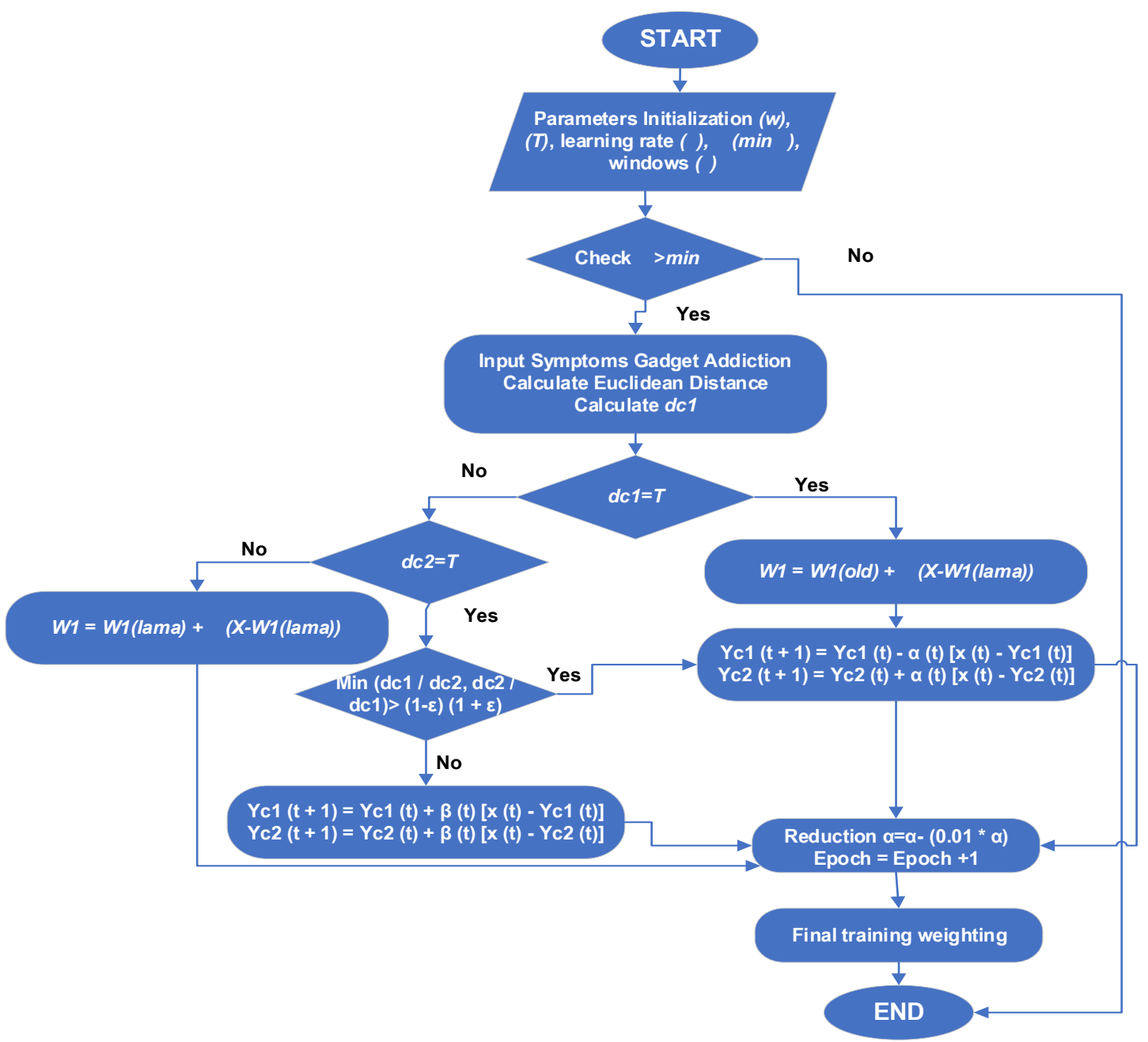

Figure 1. Flowchart process training for LVQ3

\section{RESULTS AND ANALYSIS}

a. The architecture model of LVQ3 for Children addiction

The architecture LVQ 3 model for case Children gadget addiction can be depicted in Figure 2. Figure 2 explained that X1-X34 as the number of symptoms, X-W1 to X-W2 as the distance values between 
input and weight, $\mathrm{Y}_{-}$in1 and $\mathrm{Y}$ _in2 as the activation function, and $\mathrm{F} 1$ and $\mathrm{F} 2$ as 2 classifications of level addiction.

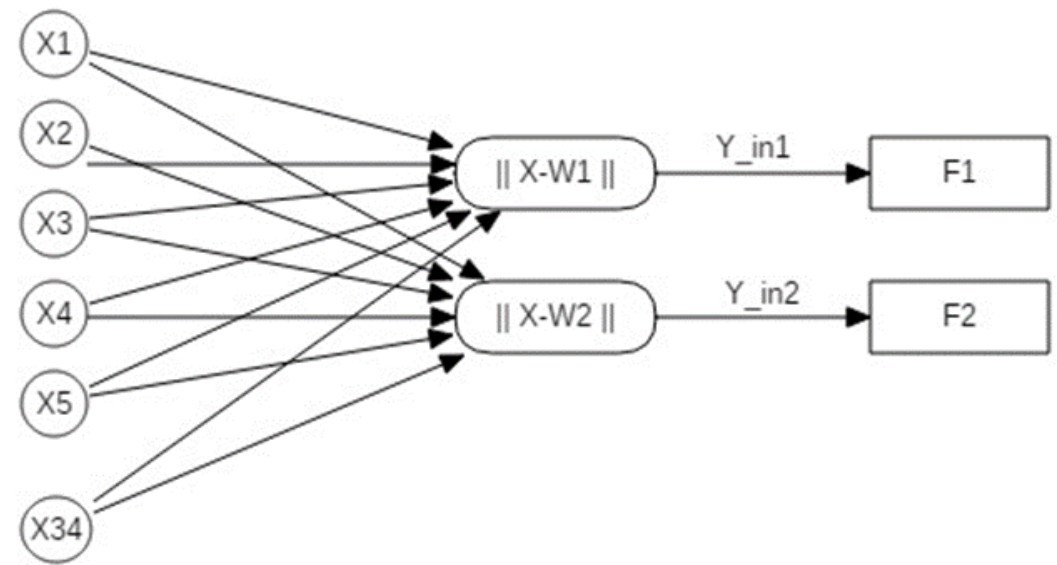

Figure 2. The LVQ 3 model for children addiction

b. Normalization

Following Equation (1) with standard values transformation for strongly agree $=5$, agree $=4$, fair $=3$, not agree $=2$, and strongly not agree $=1$, Figure 3 is illustrated the normalization process.

c. LVQ 3 Analysis

By ensuring the operational formula of LVQ3 from Equation (2-9), the sample of data classification patients is figured out in Figure 4. As a result, from 135 data, 78 children were identified as low addiction (group 1). Meanwhile, 57 data were grouped in high-level addiction (group 2). Next, 135 data have been successfully mapped into 95 (70:30), 108 (80:20), and 121(90:10) training data sharing for the evaluation stage.

d. LVQ3 Evaluation

This study used three data simulation analysis tests, including 70:30, 80:20 and 90:10, with fluctuations in the learning rate at $0.1,0.2,0.3$, window at $0.2,0.3,0.4$ and epsilon values at $0.1,0.2$, 0.3 , respectively. The performance of the LVQ3 classification based on the parameters can be seen in Figure 5 for data simulation 70:30, Figure 6 for data experiment 80:20, and Figure 7 for data simulation 90:10. Pursuing the confusion matrix function in Equation (10-11), The accuracy distinction for data simulation is explained in Table 2. It was defined in Figures 5, 6, and 7 that parameter values such as learning rate and epsilon values have an effect on classification accuracy. Thus, the higher the learning rate values, the better the training data output. 


\begin{tabular}{|c|c|c|c|c|}
\hline \multirow[t]{2}{*}{ No } & \multirow[t]{2}{*}{ Variabel } & \multicolumn{3}{|c|}{ Patient } \\
\hline & & Patient l & Patient 2 & Patientl35 \\
\hline 1 & $\mathbf{X}_{4}$ & $\begin{array}{c}\text { Strongly } \\
\text { Agree }\end{array}$ & $\begin{array}{c}\text { Strongly not } \\
\text { Agree }\end{array}$ & $\cdots$ \\
\hline 2 & $\mathrm{X}_{2}$ & Not Agree & Fair & $\ldots$ \\
\hline 3 & $\mathbf{X}_{3}$ & $\begin{array}{c}\text { Strongly } \\
\text { Agree }\end{array}$ & $\begin{array}{c}\text { Strongly not } \\
\text { Aqree }\end{array}$ & $\ldots$ \\
\hline 4 & $\mathrm{X}_{4}$ & Not Agree & Agree & $\cdots$ \\
\hline 5 & $\mathrm{X}_{5}$ & $\begin{array}{c}\text { Strongly } \\
\text { Agree }\end{array}$ & Not Agree & $\cdots$ \\
\hline 6 & $\mathbf{X}_{6}$ & Not Agree & Fair & $\cdots$ \\
\hline 7 & $\mathbf{X}_{7}$ & $\begin{array}{c}\text { Strongly } \\
\text { Agree }\end{array}$ & $\begin{array}{c}\text { Strongly not } \\
\text { Agree }\end{array}$ & $\cdots$ \\
\hline 8 & $\mathrm{X}_{8}$ & Not Agree & Fair & $\cdots$ \\
\hline 9 & $\mathrm{X}_{0}$ & $\begin{array}{c}\text { Strongly } \\
\text { Agree }\end{array}$ & Not Agree & $\cdots$ \\
\hline 10 & $\mathbf{X}_{10}$ & Not Agree & Strongly Agree & $\cdots$ \\
\hline 11 & $\mathbf{X}_{11}$ & Agree & $\begin{array}{c}\text { Strongly not } \\
\text { Agree }\end{array}$ & $\cdots$ \\
\hline 12 & $\mathbf{X}_{12}$ & $\begin{array}{c}\text { Strongly not } \\
\text { Agree }\end{array}$ & Agree & $\cdots$ \\
\hline 13 & $\mathbf{X}_{43}$ & Agree & Not Agree & $\cdots$ \\
\hline$\cdots$ & $\cdots$ & $\cdots$ & $\cdots$ & $\cdots$ \\
\hline 32 & $\mathrm{X}_{32}$ & $\begin{array}{c}\text { Strongly not } \\
\text { Agree }\end{array}$ & Strongly Agree & $\cdots$ \\
\hline 33 & $\mathbf{X}_{33}$ & Agree & Not Agree & $\cdots$ \\
\hline 34 & $\mathbf{X}_{94}$ & $\begin{array}{c}\text { Strongly not } \\
\text { Agree }\end{array}$ & Strongly Agree & $\cdots$ \\
\hline & Class & I & 1 & \\
\hline
\end{tabular}

\section{Normalization}

\begin{tabular}{|c|c|c|c|c|c|}
\hline \multirow[t]{2}{*}{ No } & \multirow{2}{*}{ Variabel } & \multicolumn{4}{|c|}{ Patient } \\
\hline & & Patient l & Patient 2 & $\ldots$ & Patientl35 \\
\hline 1 & $\mathbf{X}_{4}$ & 1 & 0 & & $\ldots$ \\
\hline 2 & $\mathrm{X}_{2}$ & 0.25 & 0.5 & & $\ldots$ \\
\hline 3 & $\mathrm{X}_{3}$ & 1 & 0 & & $\ldots$ \\
\hline 4 & $\mathrm{X}_{4}$ & 0.25 & 0.75 & & $\cdots$ \\
\hline 5 & $\mathbf{X}_{5}$ & 1 & 0.25 & & $\cdots$ \\
\hline 6 & $\mathbf{X}_{6}$ & 0.25 & 0.5 & & $\cdots$ \\
\hline 7 & $\mathbf{X}_{7}$ & 1 & 0 & & $\cdots$ \\
\hline 8 & $\mathbf{X}_{\mathrm{s}}$ & 0.25 & 0.5 & & $\cdots$ \\
\hline 9 & $\mathrm{X}_{0}$ & 1 & 0.25 & & $\cdots$ \\
\hline 10 & $\mathbf{X}_{10}$ & 0.25 & 1 & & $\cdots$ \\
\hline 11 & $\mathbf{X}_{11}$ & 0.75 & 0 & & $\cdots$ \\
\hline 12 & $\mathbf{X}_{12}$ & 0 & 0.75 & & $\cdots$ \\
\hline 13 & $\mathbf{X}_{13}$ & 0.75 & 0.25 & & $\cdots$ \\
\hline$\cdots$ & $\cdots$ & & & & $\cdots$ \\
\hline 32 & $\mathbf{X}_{32}$ & 0 & 1 & & $\cdots$ \\
\hline 33 & $\mathbf{X}_{33}$ & 0.75 & 0.25 & & $\cdots$ \\
\hline 34 & $\mathbf{X}_{34}$ & 0 & 1 & & $\cdots$ \\
\hline & Class & I & & II & \\
\hline
\end{tabular}

Figure 3. Transformation Data Process for Normalization

\begin{tabular}{|c|c|c|c|c|c|c|c|c|c|c|c|c|c|c|c|c|c|c|c|c|c|c|c|c|c|c|c|c|c|c|c|c|c|c|c|}
\hline 10 & $x 1$ & $x 2$ & $x 3$ & $\times 4$ & $x 5$ & $\times 6$ & $x 7$ & $\times 8$ & x & $x 10$ & $x 11$ & $x 12$ & $x 13$ & $x 14$ & \begin{tabular}{|l|}
$x 15$ \\
\end{tabular} & $x 16$ & $\times 17$ & \begin{tabular}{|l|l|}
$x 18$ \\
\end{tabular} & $\times 19$ & $\times 20$ & \begin{tabular}{ll|}
$x 21$ \\
\end{tabular} & \begin{tabular}{|l|}
$\times 22$ \\
\end{tabular} & $x 23$ & \begin{tabular}{|l|}
$x 24$ \\
\end{tabular} & \begin{tabular}{|l|}
$\mid x 25$ \\
\end{tabular} & $x 26$ & \begin{tabular}{|l|}
$\mid x 27$ \\
\end{tabular} & $\times 28$ & \begin{tabular}{|l|}
$x 29$ \\
\end{tabular} & \begin{tabular}{|l|}
$\times x 30$ \\
\end{tabular} & $\times 31$ & \begin{tabular}{|l|l|}
$x 32$ \\
\end{tabular} & $\times 33$ & \begin{tabular}{|l|}
$\times 34$ \\
\end{tabular} & Target \\
\hline & & 0.75 & 0.5 & 0.75 & 0.25 & 0.25 & 0.25 & 0.75 & 0.75 & 0.75 & 0.25 & 0.5 & 0.25 & 0.25 & 0.75 & 0 & & 0.75 & 0.5 & 0.5 & 0.75 & 0.25 & 0.75 & 0.25 & 0.75 & 0.25 & 0.75 & 0.25 & 0.75 & 0.5 & 0.75 & 0.25 & 0.75 & 0.25 & \\
\hline 272 & 0.75 & 0.25 & 0.25 & 0.25 & 0.75 & 0.25 & 1 & 0 & 0.25 & 0.75 & 0.25 & 0.5 & 0.75 & 0.25 & 0.25 & 0.25 & 0.75 & 0.75 & 0.5 & 0.25 & \begin{tabular}{|l|}
0.75 \\
\end{tabular} & 0 & 0.75 & 0.25 & 0.75 & 0.25 & 0.75 & 0.75 & 0.75 & 0.25 & 0.75 & 1 & 1 & 0 & \\
\hline 273 & 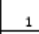 & 0.25 & 0.75 & 0.25 & 0.5 & 0.75 & 0.25 & 0.75 & 0.75 & & 0.25 & 0.25 & 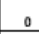 & & 0.25 & 0.75 & 0.25 & 0.75 & 0.75 & 0.25 & 0.25 & 0.75 & 0.75 & 0.25 & 0.75 & 0.25 & 0.25 & \begin{tabular}{|l|}
0.25 \\
\end{tabular} & 0 & 0.25 & 0.25 & 0.75 & 1 & 0.25 & \\
\hline 274 & & 0.75 & 0.25 & 0.75 & 0.25 & 0.25 & & 0.25 & 0.25 & 0.75 & 0.25 & 0.25 & & 1 & & 0 & & 0.75 & 0.75 & 0.75 & 0.25 & 0.75 & 0.25 & 0.75 & 0.25 & 0.25 & 0.75 & 0.25 & .25 & 0.75 & 0.25 & 0.75 & 0 & 0.75 & \\
\hline 275 & 0.75 & 0.25 & 0.25 & 0.25 & 0.5 & 0.25 & 1 & 0.25 & 0.25 & 0.75 & 0.75 & 0.25 & 0.25 & 0.75 & & 0.25 & 0.5 & 1 & 0.75 & 0.25 & 0.75 & 0.25 & 0.25 & 0.25 & 0.25 & 0.25 & 0.75 & 0.25 & 0.25 & 0.25 & 0.25 & 0.25 & 0.75 & 0.25 & \\
\hline 276 & 1 & 0.25 & 0.5 & 0.25 & 0.75 & 0.75 & 0.25 & 0.75 & 0.25 & 1 & 0.75 & 0.75 & 0.25 & 0.25 & & 0.25 & 0.75 & 0.75 & 0.75 & 0.25 & 0.75 & 0.25 & 0.25 & 0.25 & 0.25 & 0.25 & 1 & 0.25 & 0.25 & 0.25 & 0.75 & 0.25 & 0.75 & 0.25 & \\
\hline 277 & 0.75 & 0 & 0.25 & 0.25 & 0.75 & 0.25 & & 0.25 & 0.25 & 0.75 & 0.25 & 0.25 & 0.25 & 0.25 & \begin{tabular}{|l|}
0.25 \\
\end{tabular} & 0.25 & 0.75 & 0.25 & 1. & 0.25 & 0.25 & 0.25 & 0.75 & 0.25 & 0.25 & 0.25 & 0.75 & 0.75 & 0.75 & 0 & 0 & 0.25 & 0.25 & 0.25 & \\
\hline 278 & 0.75 & 0.25 & 0.5 & 0.25 & 0.75 & 0.25 & 1 & 0.25 & 0.25 & 0.25 & 0.75 & 0.25 & 0.25 & 0.25 & 0.75 & 0.25 & 0.75 & 0.25 & 0.75 & 0.25 & 1 & 0.25 & 0.25 & 0.25 & 0.75 & 0.25 & 0.75 & 0.25 & 0.75 & 0.25 & 0.75 & 0.25 & 0.75 & 0.25 & \\
\hline 279 & 1 & 0.25 & 0 & 0.75 & 0.25 & 0.75 & 0.25 & 1 & 0.25 & 0.25 & 0.25 & 0.5 & 0 & 0.25 & 0.75 & 0.25 & 0.75 & 0.25 & 1 & 0.25 & 0.75 & 0.25 & 0.25 & 0.25 & 0.75 & 0.25 & 0.75 & 0.5 & 0.75 & 0.25 & 0.75 & 0.5 & 0.75 & 0.25 & \\
\hline 280 & 0 & 0.25 & 0 & 0.25 & 0.25 & 0.25 & 0.25 & 0.25 & 0.25 & 0.75 & 0.25 & 0 & 0 & 0.25 & 1 & 1 & 0.25 & 1 & 0.75 & 0.75 & 0.75 & 0.75 & 0.25 & 1 & 0.25 & 1 & 0.25 & 0.25 & 0.75 & 0.25 & 0.75 & 0.25 & 0.5 & 0.25 & \\
\hline 281 & 0.75 & 0.75 & 0.25 & 0.25 & 0.75 & 0.25 & 0.75 & 0.25 & 0.25 & 0.25 & 0.75 & 0.75 & 0.25 & 0.25 & 0.25 & 0.25 & 0.25 & 0.25 & 0.75 & 0.25 & 0.5 & 0.25 & 0.75 & 0.75 & 0.75 & 0.75 & 0.75 & 0.25 & 1 & 0.25 & 0.75 & 0.25 & 0.75 & 0.25 & \\
\hline . & 0.75 & 0.75 & 0.25 & 0.25 & 0.5 & 0.75 & 0.25 & 0.25 & & 0.75 & 0.75 & 0.25 & 0.25 & 0.75 & 0.25 & 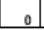 & 0.25 & & 0.715 & 0.25 & 0.75 & 0.75 & & 0.25 & 0.25 & 025 & 0.5 & 0.75 & 025 & 0.75 & 0.75 & & 0.75 & 0.75 & \\
\hline
\end{tabular}

Figure 4. Sample data of LVQ 3 Classification

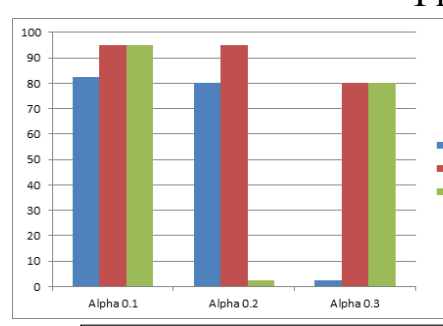

Testing for Window Value $=0.2$

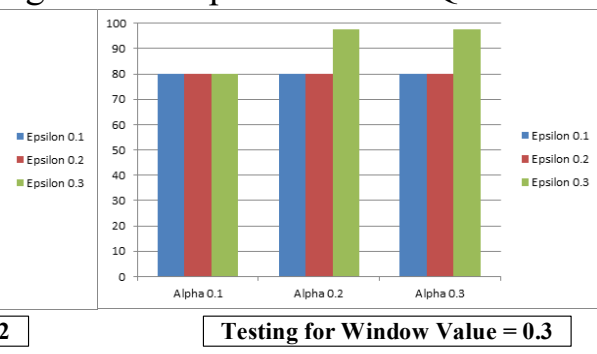

Testing for Window Value $=0.3$

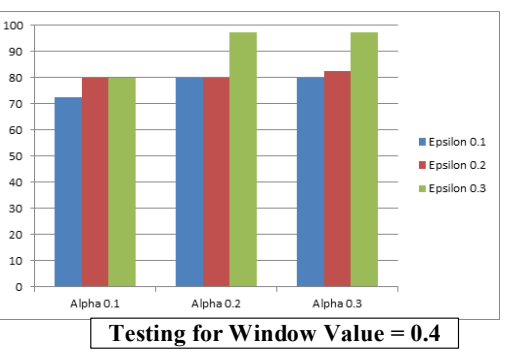

Testing for Window Value $=0.4$

Figure 5. Parameters testing values for data simulation 70:30

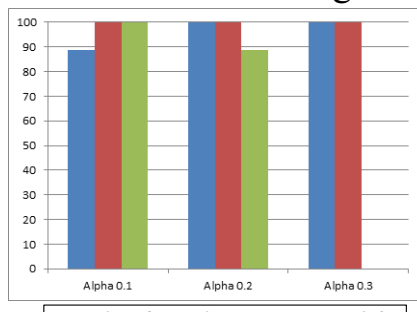

Testing for Window Value $=0.2$
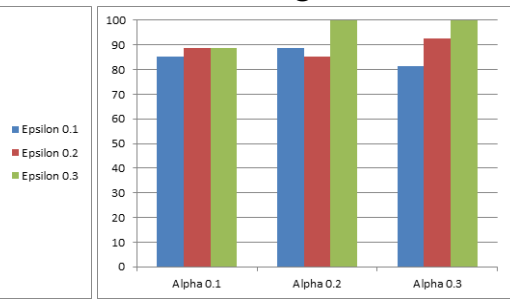

Testing for Window Value $=0.3$

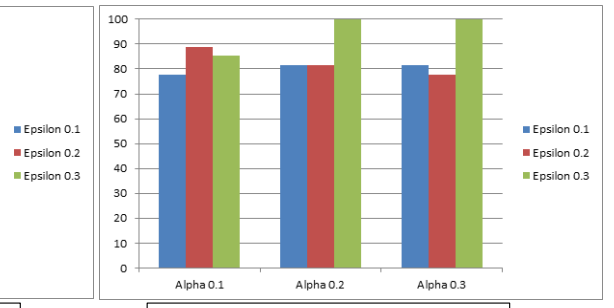

Testing for Window Value $=0.4$

Figure 6. Parameters testing values for data simulation 80:20 


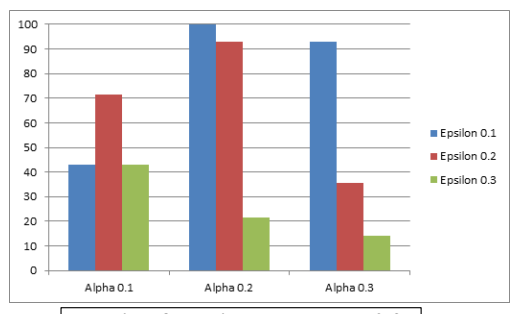

Testing for Window Value $=0.2$

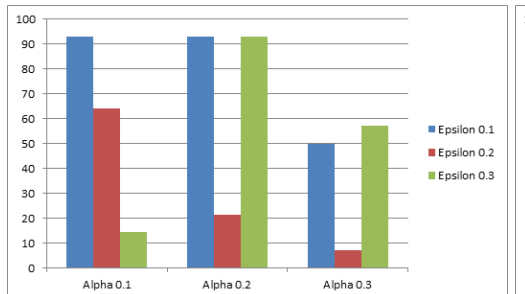

Testing for Window Value $=0.3$

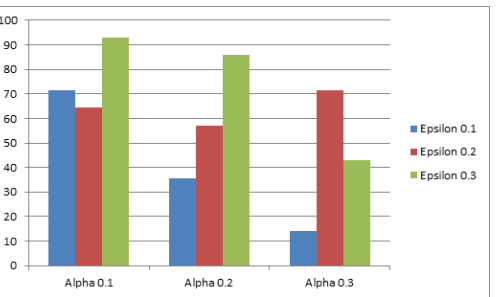

Testing for Window Value $=0.4$

Figure 7. Parameters testing values for data simulation 90:10

Table 2. The comparison of accuracy for data simulation

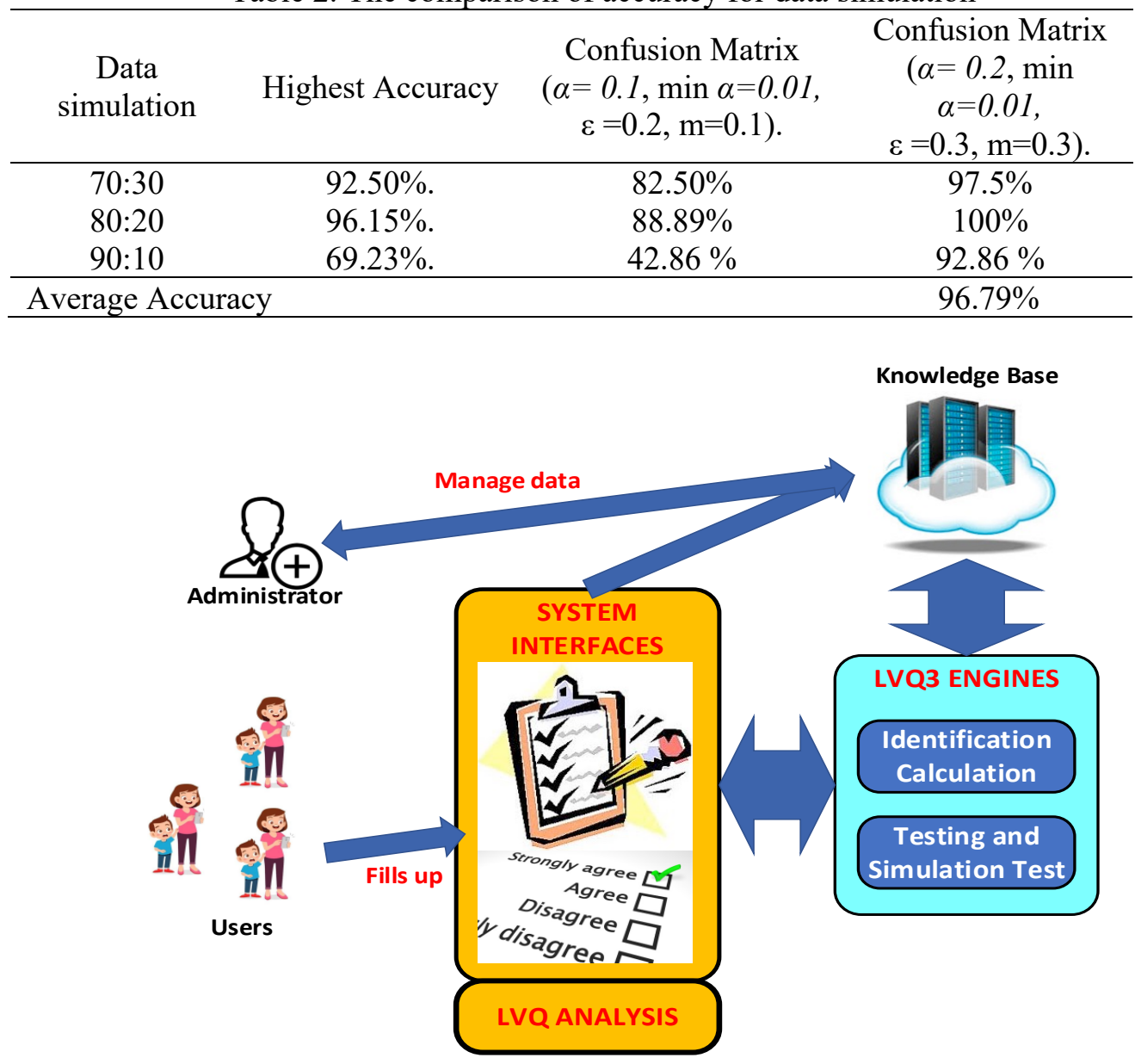

Figure 8. System Architecture

Table 2 revealed that the maximum LVQ3 classification performance is found at the value of 0.2 for learning rate, 0.01 for a decrease in the learning rate, window, and epsilon at 0.3 for 100 percent accuracy ratio data simulation at 80:20. Meanwhile, 96.79\% was the average accuracy for the entire data simulation. This appears to suggest that the level of performance of children's gadget addiction was accurately identified successfully by LVQ 3. This classification can be used as encouragement for parents to identify the behaviors of their children early on, contributing to gadget addiction. In this case study, the parents should be aware of the signs of the children that point out the enthusiasm of the children in telling about games on the gadget (X18) and playing gadget together with friends (X34), the children spend their spare time on the gadget (X30) and their playing times are often 
difficult to monitor (X22). The reaction of these side effects grows into a possible childhood gadget addiction.

e. Prototype system development

The architecture of system prototype can be seen in Figure 8. Two categories of users are supported by this application, namely managers as specialists or phycologists and patients as general users. The administrator manages the data, parameters (learning rate, windows, and epsilon values), users, LVQ3 running, and maintains the comprehensive information of the LVQ3 operation, as well as the accuracy assessment. Instead, the user entries the symptoms of the patient and end up receiving the outcome of the study since this patient are labeled as high or low gadget addiction. Blackbox and UAT fieldwork have been used to test this prototype application. Testing with Blackbox showed that all the system's functions and procedures were running well. The UAT testing of 25 end-users offers an 86.67 percent agreement that this system aids them to recognize their children's gadget addiction early on.

\section{CONCLUSION}

In assertion, with a significance accuracy of 96.79 percent, the LVQ3 algorithm has successfully established the pattern of children's addiction to the gadget. In classifying gadget addiction, the most successful parameter values are calculated at a learning rate of 0.2 down to 0.01 , window values at 0.3 , and epsilon values at 0.3 with $100 \%$ accuracy and 80:20 ratio data. The process recognition algorithm for gadget addiction has successfully been transmitted into the construction of a prototype system. This system was capable of diagnosing their children's gadget addictive nature by actually needing the extent of dependency in the class. Therefore, before getting worse, parents are urged to take curative actions in effectively treating the children. This study led to the innovation of the classification system using the LVQ3 algorithm for cases of childhood dependence. In addition, the practical implication of this paper provides parents with new information to track and assess the behaviors of children as precautions against the hazardous impacts of technology.

\section{ACKNOWLEDGEMENTS}

The author would like to thank the Universitas Islam Suska Riau Faculty of Science and Technology, Psychologist Consulting Bureau of Psychodata in Pekanbaru, the Headmaster, staff, and elementary school parents at SDN 094 Pekanbaru who assisted and information gathered for this study.

\section{REFERENCES}

[1] Rideout, V., Zero to Eight. Children's Media Use in America. Common Sense Media, 2011.

[2] The Asian Parent Insights, "Mobile device usage among young kids: A Southeast Asia study," 2014.

[3] Lenhart, A., "Teens, social media, \& technology overview," Journal of Pew Research Center, 2015.

[4] Kowalski, RM \& Whittaker, E., "Cyberbullying via social media," Journal of School Violence, vol. 14, pp. 11-29, 2014.

[5] Pebriana, PH, "Analysis of Gadget Usage on Social Interaction Ability in Early Childhood," Obsession Journal: Journal of Early Childhood Education, vol. 1, no. 1, pp. 1-11 2017.

[6] Cha, S., \& Seo, B., "Smartphone use and smartphone addiction in middle school students in Korea: Prevalence, social networking service, and game use," Health Psychology Open, pp. $1-15,2018$.

[7] Davey, A., \& Davey, S., "Assessment of smartphone addiction in Indian adolescence: a mixed method by systematic-review and meta-analysis approach," International Journal of Preventive Medicine, vol. 5, no. 12, pp. 1500-1511, 2014.

[8] Van Deursen, A., J., A., M., Bolle, C., L., Hegner, S., M., \& Kommers, P., A., M., "Modeling habitual and addictive smartphone behavior: The role of smartphone usage types, emotional intelligence, social stress, self-regulation, age, and gender, "Computers in Human Behavior, 
vol. 45, pp. 411-420, 2015.

[9] Zhao, J., Zhang, Y., Jiang, F., Ip, P., Ho, FKW, Zhang, Y., \& Huang, H., "Excessive screen time and psychosocial well-being: The mediating role of body mass index, sleep duration, and parent-child interaction, "The Journal of pediatrics, vol. 202, pp. 157-162, 2018.

[10] Lin, YH, Lin, YC, Lee, YH, Lin, PH, Lin, SH, Chang, LR, ... \& Kuo, TB, "Time distortion associated with smartphone addiction: Identifying smartphone addiction via a mobile application (App), "Journal of psychiatric research, vol. 65, pp. 139-145, 2015.

[11] World Health Organization, Gaming Disorder, 2018.

[12] McCulloch, WS, Pitts, WH, "A logical calculus of the ideas immanent in nervous activity," B Math Biol, vol. 5, pp. 115-133, 1943.

[13] Bekat, T., Erdogan, M., Inal, F., Genc, A., "Prediction of the bottom ash formed in a coal-fired 384 power plant using artificial neural networks," Energy vol. 45, pp. 882-887, 2012.

[14] Liang, T.P., Turban, E. \& Aronson, J.E., Decision support systems and intelligent systems, Yogyakarta: Penerbit Andi, 2005.

[15] Oscar, C., Melin, P., "Hybrid intelligent system for time series prediction using neural network, fuzzy logic and fractal theory," IEEE Trans. Neural Netw, vol. 13, pp. 1395-1408, 2002.

[16] Esfandiarpour-Boroujeni, I., Shamsabadi, MS, Shirani, H., Mosleh, Z., Bagheri Bodaghabadi, M., \& Salehi, MH, "Comparison of error and uncertainty of decision tree and learning vector quantization models for predicting soil classes in areas with low altitude variations, "Catena, 191 (March), pp. 104581, 2020.

[17] D. Nova and P. A. Estévez, "A review of learning vector quantization classifiers," Neural Computing and Applications. 2013.

[18] Hofmann D, Hammer B. "Kernel robust soft learning vector quantization," Lecture Notes Artif Intell, vol. 7477, pp. 14-23, 2012.

[19] Brinkrolf, C. Göpfert, and B. Hammer, "Differential privacy for learning vector quantization," Neurocomputing, vol. 342, no. Exc 277, pp. 125-136, 2019.

[20] Jasril, J., \& Sanjaya, S., "Learning Vector Quantization 3 (LVQ3) and Spatial Fuzzy C-Means (SFCM) for Beef and Pork Image Classification," Indonesian Journal of Artificial Intelligence and Data Mining, vol. 1, no. 2, pp. 60-65, 2018.

[21] S. W. Kim and B. J. Oommen, "Enhancing prototype reduction schemes with LVQ3-type algorithms," Pattern Recognit., vol. 36, no. 5, pp. 1083-1093, 2003.

[22] Israel Cruz-Vega and Hugo Jair Escalante, "Improved Learning Rule for LVQ Based on Granular Computing", in Mexican Conference on Pattern Recognition MCPR, pp.54-63, 2015.

[23] Kurniawati, D, Pengaruh Penggunaan Gadget Terhadap Prestasi Siswa. Jawa Tengah: Jurnal Ilmu Pendidikan Volume 2 Nomor 1, 2020.

[24] Setiawan, H. S, Analisis Dampak Pengaruh Game Mobile terhadap Aktivitas Pergaulan Siswa SDN Tanjung Barat 07 Jakarta. Jakarta Timur: Fakultas Teknik dan Ilmu Komputer,Universitas Indraprasta PGRI, 2018.

[25] Ahmad Ramadhan Asif and Farid Agung Rahmadi, Hubungan Tingkat Kecanduan Gagdget dengan Gangguan Emosi dan Perilaku Remaja Usia 11-12 Tahun. Jurnal Kedokteran Diponegoro, 2017.

[26] Wang, L., \& Yan, B., "Exploration of the Affecting Factors on the Quit Intentions of OnlineGame Players in China," In SHS Web of Conferences, Vol. 19, pp. 01007, 2015.

[27] A. K. Puspa, R. Loebis, and D. Nuswantoro, "Pengaruh Penggunaan Gadget terhadap Penurunan Kualitas Penglihatan Siswa Sekolah Dasar," Glob. Med. Heal. Commun., vol. 6, no. 47, pp. 28-33, 2018.

[28] Shaw, M., \& Black, D., W., "Internet Addiction: definition, assessment, epidemiology, and clinical management. CNS Drugs," vol. 2, no. 5, pp. 353-365, 2008.

[29] Hidayati, N., \& Warsito, B. (2010). Prediksi Terjangkitnya Penyakit Jantung dengan Metode Learning Vector Quantization, 21-30.

[30] J. E. Palar, F. Onibala, and W. Oroh, "Hubungan Peran Keluarga Dalam Menghindari Dampak 
Negatif Penggunaan Gadget Pada Anak Dengan Perilaku Anak Dalam Penggunaan Gadget Di Desa Kiawa 2 Barat Kecamatan Kawangkoan Utara," J. Keperawatan, vol. 6, no. 2, 2018.

[31] Sundus, M., "The Impact of Using Gadgets on Children," Journal of Depression and Anxiety", vol. 7, no. 1, pp. 1-3, 2018.

[32] Fadzil, N. M., Abdullah, M. Y., and Salleh, M. A. "The Level of Tolerance Sanctioning Children Using Gadgets by Parents Lead to Nomophobia: Early Age Gadget Exposure", International Journal of Arts \& Sciences, 615-622, 2016.

[33] Suman, P., Hegde, A. M., Unais, M., \& Jeyakumar, C, "Effect of Electronic Gadgets on the Behaviour, Academic Performance and Overall Health of School Going Children- A Descriptive Study". Journal of Advanced Medical and Dental Sciences Research, Vol. 7, Issue 1. 2019.

[34] Kim, EJ, Namkoong, K., Ku, T., \& Kim, SJ, "The relationship between online game addiction and aggression, self-control and narcissistic personality traits," European Psychiatry, vol. 23, no. 3, pp. 212-218, 2008.

[35] Lemmens, JS, Valkenburg, PM, \& Peter, J., "Psychosocial causes and consequences of pathological gaming," Computers in Human Behavior, vol. 27, no. 1, pp. 144-152, 2011.

[36] Upadhyay, Jesudass and Chitale, "Impact Of Electronic Gadgets," India International Journal of Emerging Trends in Science and Technology, Vol. 01, no. 09, pp. 1495- 1499, 2014.

[37] Sumarni, s., Pertiwi, S. T., Rukiyah, Andika, W. D., Astika, R. T., Abdurrahman, "Behavior in Early Childhood (2-3) Years: A Case Study on the Use of Gadgets in Social Environments". International Journal of Innovation, Creativity and Change, Volume 8, Issue 8, 2019.

[38] Muduli, J. R, Addiction to Technological Gadgets and Its Impact on Health and Lifestyle: A Study on College Students. India: National Institute of Technology, Rourkela. 2014.

[39] Elvia Budianita and W. Prijodiprodjo, "Application of Learning Vector Quantization (LVQ) for Classification of Child Nutritional Status," Indonesian Journal of Computing and Cybernetics Systems (IJCCS), vol. 7, n 2, pp. 155-166, 2013.

[40] A. Hinterreiter et al., "ConfusionFlow: A model-agnostic visualization for temporal analysis of classifier confusion," IEEE Trans. Vis. Comput. Graph., pp. 1-1, 2020.

\section{BIOGRAPHY OF AUTHORS}

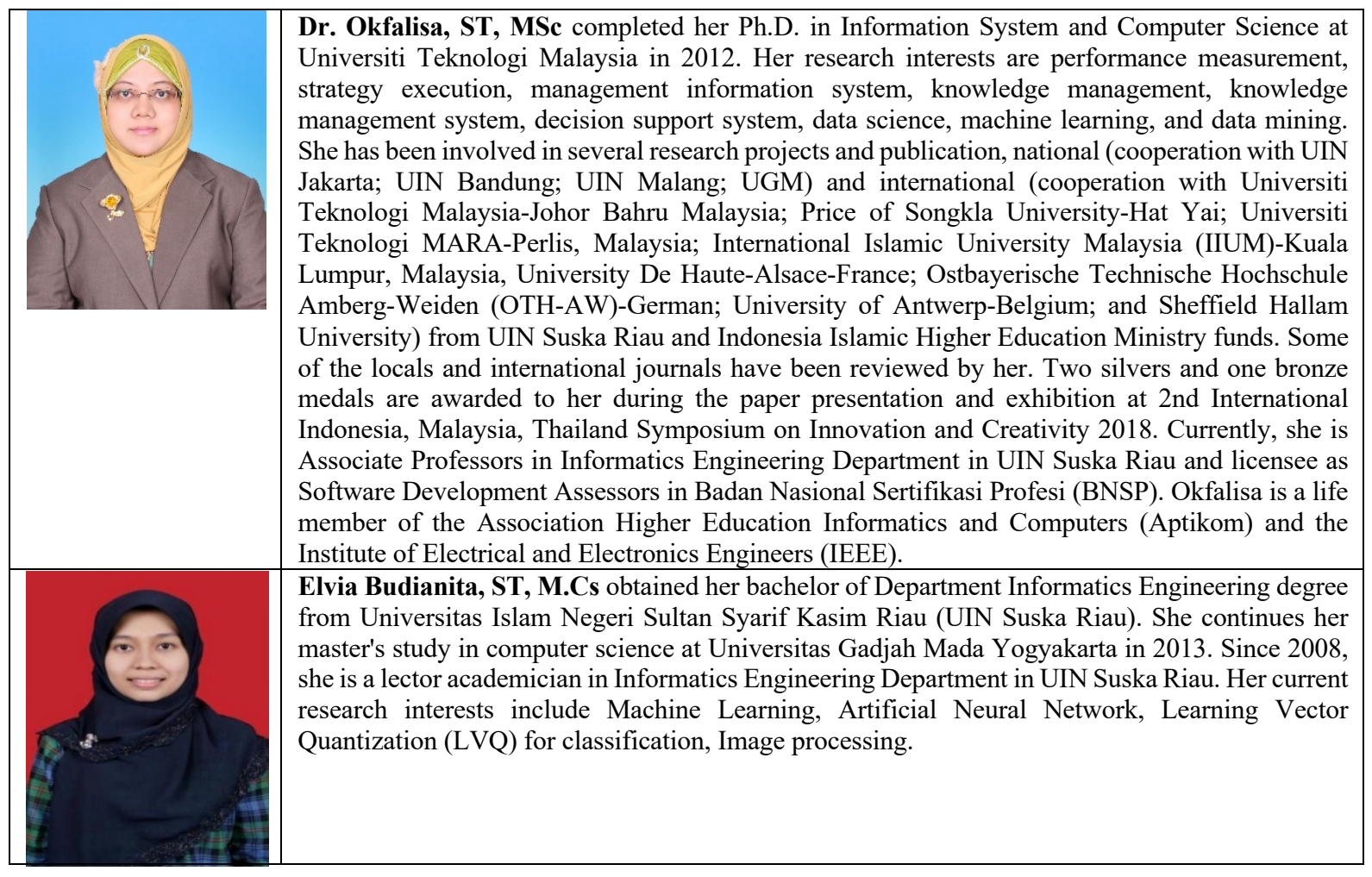

Okfalisa, The Classification of Children Gadget Addiction: The Employment of Learning Vector 


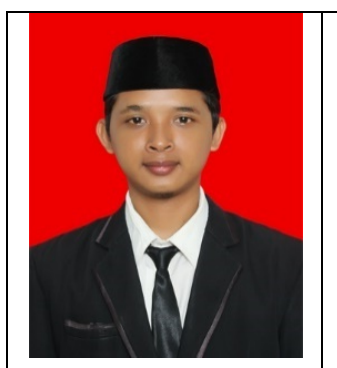

Musa Irfan, ST obtained his Bachelor of Department Informatics Engineering degree from Universitas Islam Negeri Sultan Syarif Kasim Riau in 2020. His current research interests include machine learning and datamining under Dr. Okfalisa's research team.

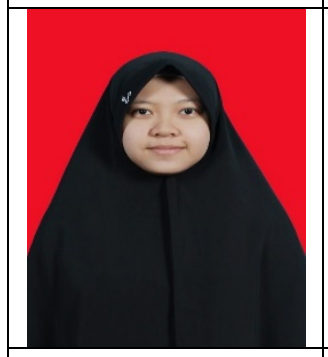

Hidayati Rusnedy, ST obtained her Bachelor of Department Informatics Engineering degree from Universitas Islam Negeri Sultan Syarif Kasim Riau in 2019. Together with Dr. Okfalisa, she conducted the research on the topics of Decision Support System with various Multi-attribute decision-making methods, including Analytical Hierarchy Process (AHP), Analytical Network Process (ANP), Fuzzy AHP, Fuzzy ANP, and MOORA. Currently, she is pursuing a master's degree in Informatics Department at the University of Pemuda Indonesia, Padang.

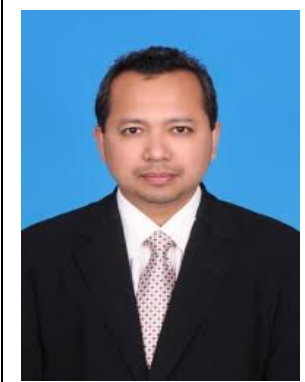

Prof. Dr. Sc. Saktioto, S.Si M.Phil CPhys, M.InstP, is an alumnus of the University of Riau who completed his bachelor's degree in Physics at the Department of Physics FMIPA 1993, He pursued to Master Degree at the University of Manchester Institute of Science and Technology (UMIST) in 2000 in Plasma Physics, and Doctoral Degree at Universiti Teknologi Malaysia in 2009 in Photonic Physics. Besides a lecturer at the University of Riau, he is also heavily involved in teaching and serving in the institutions of the Riau Province and National Government as a consultant at the Bappeda of Riau Province since 2003 as well as at District Education Offices in Riau. At the National and International level, he was involved as the OSN Team, Asian Physics Olympiad, and also the Educational Expert Team under the Ministry of National Defense. He is a Physicist and his research is carried out well at the National, Regional and International levels. In the past 10 years, he has owned more than 87 scientific articles recorded at SCOPUS, as the Chair of Nanophotonics Research on the International Photonic Joint Team from KMITL Universities in Thailand, Optiwave Companies in Canada, NUS in Singapore, Abex Companies and Universities in Malaysia, Universities in Yemen, NASA, America and Universities in England. $\mathrm{He}$ is also an active member of the International Professional agency in IEEE, OSA, APS, IOP, WASET, HFI, SPIE. Prof. Saktioto is also active as a reviewer/editorial board of more than 6 international journals in Poland, Malaysia, China, Croatia, Bulgaria, and Spain. 4 books have been published in Germany and Croatia and 3 books in Indonesia. He has won many international awards. In 2015, he was awarded as the first rank UNRI lecturer and became a national finalist lecturer finalist. In 2016, he returned as an outstanding lecturer at UNRI, and in 2017 he established research as the head of Optoelectronic research with Ton Duc Thang University in Vietnam, until 2018. Until now he is the Chair of the Indonesian Physics Association in Pekanbaru and he leads the establishment of a Global Positioning System (GPS) research with the Institute National Aeronautics and Space (LAPAN) at the Photonic Laboratory. 